\title{
Epinephrine Can Save Lives. Anaphylaxis, always a Challenge: A Therapeutic Approach on Children
}

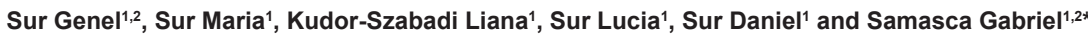

${ }^{1}$ University of Medicine and Pharmacy, Iuliu Hatieganu, Cluj-Napoca, Romania

${ }^{2}$ Emergency Clinical Hospital for Children, Cluj-Napoca, Romania

\begin{abstract}
Correct treatment of anaphylaxis in emergency events is a key point to prevent death and subsequent events Anaphylaxis can be quickly diagnosed if we recognize respiratory and circulatory manifestations and we correctly assess mental status. The first and most important treatment is epinephrine. After successful therapy, the clinician's attention must be directed toward preventing recurrences- biphasic anaphylaxis and to elucidate the causes. The patient will need to be explained the importance of preventing relapse and needs to be equipped with epinephrine, which to use in critical situations. There are differences concerning therapeutic approach, recognition of symptoms and patient education, depending on physician's experience, on patient's education level and on socio-economic level of their country.
\end{abstract}

\section{Introduction}

Anaphylaxis is a major emergency, it may have an unpredictable evolution, may progress rapidly to a fatal outcome if we don't establish the correct diagnosis, that has to be followed by rapid treatment measures.

Anaphylaxis responds promptly to treatment with epinephrine, but new episodes may occur, or at least one new episode, so-called biphasic anaphylaxis, and clinicians always have to consider this situation. From an epidemiological point of view, in most countries there is no clear evidence of cases of anaphylaxis.

Correct management of anaphylaxis requires an accurate treatment of the first episode, identifying causes and preventing future episodes [1-9].

\section{Epidemiology of Anaphylaxis}

Anaphylaxis is defined as an acute disease (minutes or hours after exposure to the allergen) with skin manifestations (general hives, itch or flushing, swollen lips-tongue-uvula), respiratory manifestations (dyspnoea, wheezing, bronchospasm, stridor, reduced peak expiratory flow, hypoxemia), decreased blood pressure and other symptoms associated with organ dysfunction (collapse, syncope, hypotonia) [10-14]. These events occur after the contact with an allergen due to mast cell degranulation, after the circulation of preformed mediators (hystamine) and newly formed (leukotrienes) [15-18]. The incidence of anaphylaxis is estimated at 30 cases per 100.000 patients per year. Regarding mortality due to anaphylaxis, there is no rigorous evidence. If we consider the prescribed epinephrine, the incidence of the child would be $1-5$ cases per 1000 patients [19-22].

It is believed that currently there is a growing tendency of anaphylaxis cases, due to widespread use of products with allergenic potential. During a year, at the Children's Hospital from Cluj have been investigated for allergic manifestations 1180 children, of whom 533 were positive. The largest number were positive to mites (232 patients), other 140 patients to animal hair, 85 children to milk, 59 to pollen, 50 to milk proteins, 25 to eggs, 26 to molds and the rest to vegetables and fruits.

Anaphylaxis was observed in 3 children, of whom one died the patient arrived too late to the hospital and the treatment was no longer efficient. In the U.S. it is estimated that food is responsible for about 30.000 cases of anaphylaxis per year, with 2.000 hospitalizations and 200 deaths. For children, the risk of anaphylaxis is 1 in 2 years for foods with 0.6 to $5 \%$ mortality per episode.

\section{Clinical Diagnosis}

Anaphylactic events are easily recognized by an experienced physician. Clinical manifestations occur in 1-15 minutes after exposure to allergen. In some cases, they can occur 30 minutes to an hour after exposure. The patient is unwell, becomes agitated, complains of tachycardia and tachypnea. Other symptoms like tingling sensations, itchy and flushed skin, throbbing in the ears, coughing, sneezing, hives and swelling (angioedema) may occur. Breathing may become difficult and wheezing may occur due to upper airways constriction and swelling. An anaphylactic reaction may progress so rapidly that it leads to collapse, cessation of breathing and loss of consciousness within 1-2 min. The reaction may be fatal unless treatment is applied immediately.

At presentation in the emergency room, anaphylaxis may not be recognised if it is triggered by a new agent, if it is an individual's first episode, or if it's an infant or a young child, or in an aphonic, dyspnoeic or unconscious individual.

The diagnosis of anaphylaxis is mainly based on the clinical history, and clinical criteria.

An anaphylactic episode is defined not only by the simultaneous involvement of two or more organs or systems, but mainly by the involvement of vital systems.

Anaphylaxis can present in various ways, in the major symptoms

*Corresponding author: Gabriel Samaşca, Department of Immunology, Croitorilor Street, 19-21 No, luliu Hatieganu, University of Medicine and Pharmacy, ClujNapoca, Romania, E-mail: Gabriel.Samasca@umfcluj.ro

Received December 04, 2011; Accepted December 26, 2011; Published January 15,2012

Citation: Genel S, Maria S, Liana KS, Lucia S, Daniel S, et al. (2012) Epinephrine Can Save Lives. Anaphylaxis, always a Challenge: A Therapeutic Approach on Children. J Aller Ther 3:e103. doi:10.4172/2155-6121.1000e103

Copyright: $\odot 2012$ Genel S, et al. This is an open-access article distributed unde the terms of the Creative Commons Attribution License, which permits unrestricted use, distribution, and reproduction in any medium, provided the original author and source are credited. 
$60 \%$ has to do with the skin (hive and flushing), but there can also be serious respiratory or cardiovascular failure, difficulty in breathing, swollen and tingling lips or a fall in a blood pressure leading to dizziness, nausea or pallor. As clinical manifestations can change, during a single episode at onset, a careful observation of the patient imposes.

The clinical presentation of anaphylaxis may vary: from one episode to another, with the time from to exposure to the trigger, the onset of symptoms, and the severity of symptoms [23-25]

\section{Differential Diagnosis}

When there is a history of recent exposure to a known allergen, anaphylaxis diagnosis is easy.

When cardiovascular and gastrointestinal manifestations predominate, diagnosis is more difficult.

\section{Respiratory pathology}

Respiratory distress syndrome; recent inhalation of foreign antibodies.

\section{Neurological}

Epileptic syndrome with hypotonia and loss of consciousness.

\section{Flushing syndromes}

Various agents have been involved in causing flushing: angiotensine converting enzyme inhibitors (histamine, kallicrein, nicotine) and carcinoid syndrome (flushing, diarrhea, colic and wheezing); medullar carcinoma of the thyroid is another important condition (persistent flushing of the face, hands and feet). Flushing syndrome is wet and dry. In the wet form caused by the postmenopausal state, sweating accompanies the flushing because of sympathetic cholinergic stimulation of the sweat gland. In carcinoid syndrome, dry flushing appears because sweat glands are not activated. In alcohol ingestion, flushing can also be present, especially within Asian people, who lack the aldehide dehydrogenase 2 enzyme. Alcohol can also lead to flushing in patients with Hodgkin's disease, hypereosinophilia syndrome and splenectomy.

\section{Restaurant syndrome}

Scombroid-fish poisoning due to histamine has been described in adults and children (fish colonized by enterobacteria - Klebsiella oxytoca and Morganella morgani) can contain histamine derivated from histidine through bacterial action. The Chinese restaurant syndrome caused by monosodium glutamate in foods may also provoke flushing, headache and abdominal symptoms.

Sulphites from preservatives in gelatin, sauces, wine, fruit juices, cheese, mollusks can cause the same symptoms as monosodium glutamate.

Vasovagal reactions are a reflex of the involuntary nervous system causing bradycardia, hypotension and vasodilatation. Vasovagal syndromes are generally caused by physical or emotional stress and characterized by pallor, asthenia,nausea,hypotension,vomiting and profuse sweating.

\section{Excess of endogenous histamine production}

The Vancomycin induced red man syndrome, mediated by histamine systemic mastocytosis can determinate anaphylactic acute syndrome.
Promyelocytic leukemia and basophilic leukemia treated with Treonin can also cause anaphylactic reaction.

Echinococal cysts may be a possible cause of anaphylactic episode via histamine.

\section{Psychogenic conditions}

Munchausen syndrome, globus hystericus and panic attacks cam imitate anaphylactic symptoms.

\section{Another allergic manifestation}

Hereditary angioedema can mimic anaphylactis attacks. These patients have usually had episodes triggered by trivial traumas such as oral or dental manipulations. Prompt recongnition of this attacks may be critical, as long as oedema of the tongue and upper airways is the cause of death in $15-30 \%$ of this patients.

The systemic capillary leak symdrome, a severe sometimes fatal idiophatic condition with shock and massive edema, often after a nonspecific prodrome of weakness, fatigue, and myalgias is also one of the differential diagnosis.

Gleich's syndrome is characterized by episodic urticaria/ angioedema, hypereosinophilia and elevation of immunoglobulin $\mathrm{M}$ [26-32].

\section{Laboratory Diagnosis}

The diagnosis is primarly clinical but laboratory tests may bring additional information: IgE mediated anaphylaxis. More valuable is the measurement of metabolites such as: tryptase, plasma and urinary Histamine [33-36].

\section{Emergency Treatment of Anaphilaxis}

The elements of the intervention to be rapidly activated can be summarized in the mneomonic airway patency, breathing, circulation and mental status (ABCM). The patient must be kept horizontal, with raised legs, to promote the perfusion of vital organs [37-39].

Epinephrine must be injected intramuscular (s.c is not recommended because local vasoconstriction can reduce deposition. The substance should be injected intramusculary in the tigh, on the lateral part of the quadriceps or in the deltoid muscle.

The dose is $0.01 \mathrm{mg} / \mathrm{kg}$ of aqueous Epinephrine 1:100 (up to $0.5 \mathrm{ml}$ to be repeated if necessary after 5-30 minutes).

If the patient's weight is unknown, an approximate dosage is 50 $\mu \mathrm{g}(50 \mu \mathrm{g}-0.05 \mathrm{ml}$ for infants less then 6 months; $120 \mu \mathrm{g}-0.12 \mathrm{ml}$ for children between 6 month to 6 years; $250 \mu \mathrm{g}-0.25 \mathrm{ml}$ from 6 to 12 years; $500 \mu \mathrm{g}-0.5 \mathrm{ml}$ for children older than 12 years).

During the administration of Epinephrine, vital signs-cardiac activity, respiratory function and blood pressure should be continuously monitored and airways patency should be continuously maintained to prevent rapid worsening.

If symptoms do not decrease:

1. Repeat Epinephrine after 5 minutes;

2. Establish a venuous acces; in hypotension rapidly administer isotonic saline solution, $20-30 \mathrm{ml} / \mathrm{h}$ in the first hour;

3. If hypotension persists rapid diffusion of volume expanders;

4. Administer oxygen: 5-8 1/min; 
Citation: Genel S, Maria S, Liana KS, Lucia S, Daniel S, et al. (2012) Epinephrine Can Save Lives. Anaphylaxis, always a Challenge: A Therapeutic Approach on Children. J Aller Ther 3:e103. doi:10.4172/2155-6121.1000e103

5. Administer support drugs: antihistamines (Clorpheniramine), bronchodilators (Salbutamol), corticosteroids (Hydrocortisone), glucagons, Dopamine.

Antihistamines are indicated for treatment of pruritus and urticaria. Clorpheniramine is used in a dose of $1 \mathrm{mg} / \mathrm{kilo}$; other antihistamines: Levocetirizine, Desloratadine.

Salbutamol can be used for relief of bronchospasm.

Methylprednisolone is used in a dose of 1-2 $\mathrm{mg}$ /day i.v.

Biphasic Anaphylaxis can be developed after as many $20 \%$ of anaphylaxis. The interval between the first anaphylactic reaction and the subsequent fatal or near fatal anaphylactic episode can last between 2 to 12 hours, and no specific symptom is predictive of recurrences. One Ephinephrine injection is similar to first episode ?? Systemic corticosteroids are unable to prevent recurrence [40-44].

\section{Conclusion}

The emergency department is very important for anaphylaxis treatment and the prevention of subsequent recurrences.

\section{References}

1. Kobrynski LJ (2007) Anaphylaxis. Clin Ped Emerg Med 8: 110-116.

2. Sampson HA, Munoz-Furlong A, Bock SA, Schmidt C, Bass R, et al. (2005) Symposium on the definition and management of anaphylaxis: summary report. J Allergy Clin Immunol 115: 584-591.

3. Sampson HA, Munoz-Furlong A, Campbell RL, Adkinson NF, Bock SA, et al. (2006) Second symposium on the definition and management of anaphylaxis: summary report--Second National Institute of Allergy and Infectious Disease/ Food Allergy and Anaphylaxis Network symposium. J Allergy Clin Immunol 117: 391-397.

4. Joint Task Force on Practice Parameters, American Academy of Allergy, Asthma and Immunology; American College of Allergy, Asthma and Immunology and Joint Council of Allergy, Asthma and Immunology (2005) The diagnosis and management of anaphylaxis: an updated practice parameter. J Allergy Clin Immunol 115: S483-523.

5. Martelli A, Ghiglioni D, Sarratud T, Calcinai E, Veehof S, et al. (2008) Anaphylaxis in the Emergency Department: A Paediatric Perspective. Curr Opin Allergy Clin Immunol 2008 8: 321-329.

6. Lieberman P (2005) Biphasic anaphylactic reactions. Ann Allergy Asthma Immunol 95: 217-226.

7. Simons FE (2008) Anaphylaxis. J Allergy Clin Immunol 121: S402-407.

8. Lieberman P, Kemp SF, Oppenheimer JJ. Lang DM, Bernstein IL, et al. (2005) The diagnosis and management of anaphylaxis: an updated practice parameter. J Allergy Clin Immunol 115: S485-S523.

9. Lieberman $P$ (2003) Use of epinephrine in the treatment of anaphylaxis. Curr Opin Allergy Clin Immunol 3: 313-318.

10. Brown SG (2004) Clinical features and severity grading of anaphylaxis. J Allergy Clin Immunol 114: 371-376.

11. Braganza SC, Acworth JP, McKinnon DR, Peake JE, Brown AF (2006) Paediatric emergency department anaphylaxis: different patterns from adults. Arch Dis Child 91: 159-163

12. Brown SGA (2005) Cardiovascular aspects of anaphylaxis: implications for treatment and diagnosis. Curr Opin Allergy Clin Immunol 5: 359-364

13. Wang J, Sampson HA (2007) Food anaphylaxis. Clin Exp Allergy 37: 651-660.

14. Greenberger PA (2007) Idiopathic anaphylaxis. Immunol Allergy Clin North Am 27: 273-293.

15. Ogawa Y, Grant JA (2007) Mediators of anaphylaxis. Immunol Allergy Clin North Am 27: 249-260.

16. Macdougall CF, Cant AJ, Colver AF (2002) How dangerous is food allergy in childhood? The incidence of severe and fatal allergic reactions across the UK and Ireland. Arch Dis Child 86: 236-239.
17. Bock SA, Munoz-Furlong A, Sampson HA (2001) Fatalities due to anaphylactic reactions to foods. J Allergy Clin Immunol 107: 191-193.

18. Kemp SF, Lockey RF (2002) Anaphylaxis: a review of causes and mechanisms J Allergy Clin Immunol 110: 341-348.

19. Bohlke K, Davis RL, DeStefano F, Marcy SM, Braun MM, et al. (2004) Epidemiology of anaphylaxis among children and adolescents enrolled in a health maintenance organization. J Allergy Clin Immunol 113: 536-542.

20. Lieberman P, Camargo CA, Bohlke K, Jick H, Miller RL, et al. (2006) Epidemiology of anaphylaxis: findings of the American College of Allergy, Asthma and Immunology Epidemiology of Anaphylaxis Working Group. Ann Allergy Asthma Immunol 97: 596-602.

21. Simons FE, Peterson S, Black CD (2002) Epinephrine dispensing patterns for an out-of-hospital population: a novel approach to studying the epidemiology of anaphylaxis. J Allergy Clin Immunol 110: 647-651.

22. Sheikh A, Alves B (2001) Age, sex, geographical and socio-economic variations in admissions for anaphylaxis: analysis of four years of English hospital data. Clin Exp Allergy 31: 1571-1576.

23. Muraro A, Roberts G, Clark A, Eigenmann PA, Halken S, et al. (2007) The management of anaphylaxis in childhood: position paper of the European academy of allergology and clinical immunology. Allergy 62: 857-871.

24. Brown AF, McKinnon D, Chu K (2001) Emergency department anaphylaxis: a review of 142 patients in a single year. J Allergy Clin Immunol 108: 861-866.

25. Smit DV, Cameron PA, Rainer TH (2005) Anaphylaxis presentations to an emergency department in Hong Kong: incidence and predictors of biphasic reactions. J Emerg Med 28: 381-388.

26. Lee JM, Greenes DS (2000) Biphasic anaphylactic reactions in pediatrics. Pediatrics 106: 762-766

27. Brazil E, MacNamara AF (1998) "Not so immediate" hypersensitivity-the danger of biphasic anaphylactic reactions. J Accid Emerg Med 15: 252-253.

28. Golden DB (2007) Insect sting anaphylaxis. Immunol Allergy Clin North Am 27: $261-272$.

29. Amin HS, Liss GM, Bernstein DI (2006) Evaluation of near-fatal reactions to allergen immunotherapy injections. J Allergy Clin Immunol 117: 169-175.

30. Lieberman P (2009) Anaphylaxis. In: Adkinson NF, Bochner BS, Busse WW Holgate ST, Lemanske RF, Simons FER, eds. Middleton's Allergy: Principles and Practice. 7th. Philadelphia :1027-1049.

31. Webb LM, Lieberman P (2006) Anaphylaxis: a review of 601 cases. Ann Allergy Asthma Immunol 97: 39-43.

32. Greenberger PA, Rotskoff BD, Lifschultz B (2007) Fatal anaphylaxis: postmortem findings and associated comorbid diseases. Ann Allergy Asthma Immunol 98: 252-257.

33. Romano A, Di Fonso M, Giuffreda F, Papa G, Artesani MC (2001) Fooddependent exercise-induced anaphylaxis: clinical and laboratory findings in 54 subjects. Int Arch Allergy Immunol 125: 264-272.

34. Pumphrey RS (2000) Lessons for management of anaphylaxis from a study of fatal reactions. Clin Exp Allergy 30: 1144-1150.

35. Lieberman P, Nicklas RA, Oppenheimer J, Kemp SF, Lang DM, et al. (2010) The diagnosis and management of anaphylaxis practice parameter: 2010 update. J Allergy Clin Immunol 126: 477-480.

36. Boyce JA, Assa'ad A, Burks AW, Jones SM, Sampson HA, et al. (2010) Guidelines for the diagnosis and management of food allergy in the United States: report of the NIAID-sponsored expert panel. J Allergy Clin Immunol 126 1105-1118.

37. Alrasbi M, Sheikh A (2007) Comparison of international guidelines for the emergency medical management of anaphylaxis. Allergy 62: 838-841.

38. Simons FE, Ardusso LR, Bilò MB, El-Gamal YM, Ledford DK, et al. (2011) World Allergy Organization anaphylaxis guidelines: summary. J Allergy Clin Immunol 127: 587-593.

39. Nurmatov U, Worth A, Sheikh A (2008) Anaphylaxis management plans for the acute and long-term management of anaphylaxis: a systematic review. $J$ Allergy Clin Immunol 122: 353-361.

40. Kemp SF, Lockey RF, Simons FE (2008) Epinephrine: the drug of choice for anaphylaxis. A statement of the World Allergy Organization. Allergy 63: 1061 1070. 
Citation: Genel S, Maria S, Liana KS, Lucia S, Daniel S, et al. (2012) Epinephrine Can Save Lives. Anaphylaxis, always a Challenge: A Therapeutic Approach on Children. J Aller Ther 3:e103. doi:10.4172/2155-6121.1000e103

Page 4 of 4

41. Sheikh A, Shehata YA, Brown SG, Simons FE (2009) Adrenaline for the treatment of anaphylaxis: cochrane systematic review. Allergy 64: 204-212

42. Simons EFR (2004) Advances in H1-antihistamines. N Engl J Med 351: 22032217.
43. Sheikh A, Ten Broek V, Brown SG, Simons FE (2007) H1-antihistamines for the treatment of anaphylaxis: cochrane systematic review. Allergy 62: 830-837.

44. Choo KJ, Simons E, Sheikh A (2010) Glucocorticoids for the treatment of anaphylaxis: cochrane systematic review. Allergy 65: 1205-1211. 